\title{
Purification and Properties of a Cellulase from Aspergillus niger
}

\author{
By PAUL L. HURST, JAN NIELSEN, ${ }^{*}$ PATRICK A. SULliVAN and \\ MAXWELL G. SHEPHERD \\ Department of Biochemistry, University of Otago, Dunedin, New Zealand
}

(Received 15 November 1976)

\begin{abstract}
A cellulolytic enzyme was isolated from a commercial cellulase preparation from Aspergillus niger. A yield of about $50 \mathrm{mg}$ of enzyme was obtained per $100 \mathrm{~g}$ of commercial cellulase. The isolated enzyme was homogeneous in the ultracentrifuge at $\mathrm{pH} 4.0$ and 8.0, and in sodium dodecyl sulphate/polyacrylamide-gel electrophoresis but showed one major and two minor bands in disc gel electrophoresis. No carbohydrate was associated with the protein. Amino acid analysis revealed that the enzyme was rich in acidic and aromatic amino acids. Data from the amino acid composition and dodecyl sulphate/ polyacrylamide-gel electrophoresis indicated a molecular weight of 26000 . The purified enzyme was active towards CM-cellulose, but no activity towards either cellobiose or $p$-nitrophenyl $\beta$-D-glucoside was detected under the assay conditions used. The $\mathrm{pH}$ optimum for the enzyme was $\mathrm{pH} 3.8-4.0$, and it was stable at $25^{\circ} \mathrm{C}$ over the range $\mathrm{pH} 1-9$; maximum activity (at pH4.0) was obtained at $45^{\circ} \mathrm{C}$. The cellulase was more stable to heat treatment at $\mathrm{pH} 8.0$ than at 4.0. Kinetic studies gave $\mathrm{pK}$ values between 4.2 and 5.3 for groups involved in the enzyme-substrate complex.
\end{abstract}

It is well established that Aspergillus niger produces a number of cellulolytic enzymes. Commercial crude cellulase preparations, derived from culture filtrates of the fungus, have been fractionated by several workers (Whistler \& Smart, 1953; Wolf et al., 1959; Krishna Murti \& Stone, 1961; Li \& King, 1963; Pettersson, 1963; Clarke \& Stone, 1965a; Ikeda et al., 1967). Ikeda et al. $(1973 a, b)$ have reported the isolation of a homogeneous cellulolytic enzyme from $A$. niger, with an unusually low optimum pH (2.5). The other activities of $A$. niger have not, however, been fully characterized .

The aim of our study is to examine the mechanism of action of a cellulase, and the present paper describes the purification, physicochemical and enzymic properties of a 1,4- $\beta$-glucan glucanohydrolase (EC 3.2.1.4) from $A$. niger.

\section{Experimental}

\section{Materials}

Cellulase (type II, practical grade), $p$-nitrophenyl $\beta$-D-glucoside, 2-nitrophenylsulphenyl chloride and 5,5'-dithiobis-(2-nitrobenzoic acid) were purchased from Sigma Chemical Co., St. Louis, MO, U.S.A. CM-cellulose 7LIXP was obtained from Hercules Inc., Wilmington, DE, U.S.A. p-Hydroxybenzoic acid hydrazide was from Fluka AG, Buchs, Switzerland. Glucose oxidase and cellobiose were

\footnotetext{
* Deceased.
}

from BDH Chemicals Ltd., Poole, Dorset, U.K. $\left(\mathrm{NH}_{4}\right)_{2} \mathrm{SO}_{4}$ (special enzyme grade) was obtained from Mann Research Laboratories, New York, NY, U.S.A. Cellulose powder (chromatography grade) was from J. T. Baker Chemical Co., Phillipsburgh, NJ, U.S.A. Bio-Gel P-60 was from Bio-Rad Laboratories, Richmond, CA, U.S.A. All other chemicals used were of analytical-reagent grade.

\section{Methods}

Determination of protein. Protein concentration was measured by a modification (Eggstein \& Kreutz, 1967) of the method of Lowry et al. (1951), with crystalline bovine serum albumin as a standard. The $A_{280}$ was used for monitoring protein in column effluents.

Determination of reducing sugars. Reducing end groups were measured by a modification of the method of Lever (1973). p-Hydroxybenzoic acid hydrazide reagent was prepared immediately before use, by mixing $5 \mathrm{ml}$ of each of the stock solutions (1 $\mathrm{M}-\mathrm{Na}_{2} \mathrm{SO}_{3}, 0.2 \mathrm{M}-\mathrm{CaCl}_{2}, \quad 0.5 \mathrm{M}$-trisodium citrate and $5 \mathrm{M}-\mathrm{NaOH}$ ) and diluting to $90 \mathrm{ml}$ with water; $1.0 \mathrm{~g}$ of $p$-hydroxybenzoic acid hydrazide was dissolved in the solution, which was then diluted to $100 \mathrm{ml}$. $p$-Hydroxybenzoic acid hydrazide reagent $(5 \mathrm{ml})$ was added to $0.6 \mathrm{ml}$ of a solution of reducing sugar, mixed, and heated on a boiling-water bath for $10 \mathrm{~min}$. The samples were then cooled by immersing in cold water and the $A_{\mathbf{2 4 0}}$ was determined.

Assay of cellulase. Cellulase activity was measured 
by the appearance of reducing end groups in a solution of CM-cellulose. CM-cellulose was dissolved in $0.1 \mathrm{M}$-sodium acetate buffer, $\mathrm{pH} 4.0$, to a final concentration of $10 \mathrm{mg} / \mathrm{ml}$. Substrate solution $(0.5 \mathrm{ml})$ and $0.1 \mathrm{ml}$ of a suitable dilution of enzyme (diluted in the sodium acetate buffer) were mixed and incubated at $40^{\circ} \mathrm{C}$ for $30 \mathrm{~min}$. The reducing sugars produced were then determined. An absolute definition of a unit of cellulase activity is difficult. This is because in the substrate the glucose molecules are substituted with carboxymethyl groups, and the products of the enzyme reaction are heterogeneous polymers; the effect of this on the absorption coefficient of reducing end groups is not known. It is not therefore valid to use a glucose standard to determine the number of $\mu \mathrm{mol}$ of reducing end groups. In addition there is little to be gained by expressing the activity in terms of glucose equivalents, since glucose is not a product of the enzyme reaction. In the present work a unit of activity is defined as the amount of enzyme that produces an $A_{420}$ of 0.10 under the conditions defined.

Assay of cellobiase. Cellobiase activity was determined by measuring the release of glucose from a solution of cellobiose. To $0.5 \mathrm{ml}$ of cellobiose solution $(10 \mathrm{mg} / \mathrm{ml})$ in $0.1 \mathrm{M}$-sodium acetate buffer, $\mathrm{pH} 4.0$, $0.1 \mathrm{ml}$ of enzyme solution was added. The mixture was then incubated at $40^{\circ} \mathrm{C}$ for $30 \mathrm{~min}$ and the glucose released was measured by the glucose oxidase procedure of Lloyd \& Whelan (1969).

Assay of $\beta$-glucosidase. The substrate for the determination of $\beta$-glucosidase activity was $p$-nitrophenyl $\beta$-D-glucoside. The assay mixture contained $2.0 \mathrm{ml}$ of $1 \mathrm{mM}$ - $p$-nitrophenyl $\beta$-D-glucoside in $0.1 \mathrm{M}$ sodium acetate buffer, $\mathrm{pH} 5.0$, and $0.1 \mathrm{ml}$ of enzyme solution. After incubation at $40^{\circ} \mathrm{C}$ for $30 \mathrm{~min}$, $0.5 \mathrm{ml}$ was removed and added to $10 \mathrm{ml}$ of $0.1 \mathrm{M}$ $\mathrm{Na}_{2} \mathrm{CO}_{3}$. $p$-Nitrophenol released was measured by the $A_{400}$.

Determination of carbohydrate. Total carbohydrate was measured by the orcinol/ $/ \mathrm{H}_{2} \mathrm{SO}_{4}$ method of Svennerholm (1956), by using glucose as standard.

Preparation of alkali-swollen cellulose. This was prepared by the method of Hash \& King (1958).

Gel chromatography. A column $(2.2 \mathrm{~cm} \times 47 \mathrm{~cm})$ of Bio-Gel P-60 was calibrated for molecular-weight determination by the method of Andrews (1964), by using $0.05 \mathrm{M}$-Tris/ $\mathrm{HCl} / 0.1 \mathrm{M}-\mathrm{KCl}$ buffer, $\mathrm{pH} 7.5$.

Ultracentrifuge studies. Sedimentation-velocity analyses were performed in a Spinco model E analytical ultracentrifuge, equipped with schlieren optics, in a standard $12 \mathrm{~mm}$ single-sector cell and an analytical D rotor. Sedimentation coefficients were determined by the method of Schachman (1957).

Polyacrylamide-gel electrophoresis. The method of Hedrick \& Smith (1968) was used for disc gel electrophoresis in $7.5 \%(\mathrm{w} / \mathrm{v})$ polyacrylamide.
Electrophoresis in $7.5 \%(\mathrm{w} / \mathrm{v})$ polyacrylamide was carried out in continuous buffer systems $(0.05 \mathrm{M}$ pyridine/acetic acid, $\mathrm{pH} 5.5$, and $0.05 \mathrm{M}$-Tris/acetate, pH 8.0) by the method of Hjertén et al. (1965). SDS*/ polyacrylamide-gel electrophoresis was performed by the technique of Weber \& Osborn (1969). Gels were stained with Coomassie Brilliant Blue (Weber \& Osborn, 1969). When required, unstained gels were scanned at $280 \mathrm{~nm}$ with a Joyce-Loebl u.v. scanner (type D8 MK2), frozen with solid $\mathrm{CO}_{2}$ and sliced in $1 \mathrm{~mm}$ sections by using a Mickle gel slicer. Protein loads of up to $180-200 \mu \mathrm{g}$ were used with all gel systems. The molecular weights of marker proteins used in the SDS/polyacrylamide-gel electrophoresis and gel-chromatography experiments were from tables compiled by Smith (1968).

Amino acid analysis. Three samples, each containing $0.5 \mathrm{mg}$ of purified enzyme and a crystal of phenol, were hydrolysed under nitrogen in $6 \mathrm{M}-\mathrm{HCl}$ at $110^{\circ} \mathrm{C}$ for 24,48 and $72 \mathrm{~h}$ respectively. The hydrolysates were analysed in a Jeol JLC-6AH amino acid analyser and the data computed in part by using a program developed for a Hewlett-Packard 9821 A calculator. Average values were used for all amino acids except serine, threonine, phenylalanine and tyrosine, where zero-time values were calculated by extrapolation. Free thiol groups were determined spectrophotometrically by using 5,5'-dithiobis-(2-nitrobenzoicacid) in $8 \mathrm{M}$-urea or $2 \%(\mathrm{w} / \mathrm{v})$ SDS (Habeeb, 1972). Cystine was measured as cysteine by using 5,5'-dithiobis(2-nitrobenzoic acid) after the cellulase was reduced with $\mathrm{NaBH}_{4}$ in the presence of $8 \mathrm{M}$-urea (Habeeb, 1972). Tryptophan was determined by the method of Edelhoch (1967) and by labelling with 2-nitrophenylsulphenyl chloride in $50 \%(\mathrm{v} / \mathrm{v})$ acetic acid (Scoffone et al., 1968).

Kinetic analyses. The kinetic parameters $K_{\mathrm{m}}$ and $V$ were derived from data analysed by the direct linear plot (Eisenthal \& Cornish-Bowden, 1974), by using a program developed for the Hewlett-Packard calculator. Velocities were expressed as units $/ \mu \mathrm{g}$ of protein and $K_{\mathrm{m}}$ values as $\mathrm{mg}$ of CM-cellulose $/ \mathrm{ml}$.

Purification of cellulase. All operations were carried out at $4^{\circ} \mathrm{C}$. The crude cellulase powder $(100 \mathrm{~g})$ was suspended in 1 litre of $0.05 \mathrm{M}$-ammonium formate buffer, $\mathrm{pH} 4.0$, stirred for $12 \mathrm{~h}$ and then insoluble material was removed by centrifugation $(15 \mathrm{~min}$ at $20000 \mathrm{~g})$. The cellulase was then purified by the scheme given in Table 1. Column-chromatography eluates were concentrated by freeze-drying. After the $\left(\mathrm{NH}_{4}\right)_{2} \mathrm{SO}_{4}$ precipitation, the supernatant was desalted on a column $(3 \mathrm{~cm} \times 30 \mathrm{~cm})$ of Sephadex G-25 equilibrated with the ammonium formate buffer. The eluate (approx. $600 \mathrm{ml}$ ) was then percolated through a column $(5 \mathrm{~cm} \times 20 \mathrm{~cm})$ of DEAESephadex A-25 equilibrated with the formate buffer

* Abbreviation: SDS, sodium dodecyl sulphate. 
(flow rate approx. $60 \mathrm{ml} / \mathrm{h}$ ) and concentrated. A gelatinous precipitate was removed by centrifuging and the supernatant was layered on to a column $(5 \mathrm{~cm} \times 100 \mathrm{~cm})$ of Sephadex G-75 and eluted with the formate buffer at a rate of $50 \mathrm{ml} / \mathrm{h}$. Fractions $90-130$ $(12.5 \mathrm{ml})$ associated with the cellulolytic activity were pooled and concentrated.

The freeze-dried residue was dissolved in $10 \mathrm{ml}$ of $0.05 \mathrm{M}$-ammonium acetate buffer, $\mathrm{pH} 5.5$, and applied to an alkali-swollen cellulose column $(2.5 \mathrm{~cm} \times 90 \mathrm{~cm})$. The column was eluted with acetate buffer at a rate of $20 \mathrm{ml} / \mathrm{h}$. Fractions containing more than $50 \%$ of the activity found in the peak fraction were pooled. This solution was freeze-dried and dissolved in $10 \mathrm{ml}$ of 5 mm-sodium phosphate buffer, $\mathrm{pH} 6.5$, and equilibrated with that buffer by passage through a column $(2.2 \mathrm{~cm} \times 22 \mathrm{~cm})$ of Sephadex G-25. This eluate was then applied to a column $(5 \mathrm{~cm} \times 15 \mathrm{~cm})$ of hydroxyapatite-Sephadex G-25. The ratio of hydroxyapatite/ Sephadex G-25, added to improve the flow rate, was 1:2 (v/v) of swollen components. The column was equilibrated with $5 \mathrm{~mm}$-sodium phosphate buffer and eluted stepwise with 5, 10, 50, 100 and $500 \mathrm{~mm}$ sodium phosphate buffers, $\mathrm{pH} 6.5$, at the rate of $20 \mathrm{ml} / \mathrm{h}$. All cellulolytic activity appeared in the $5 \mathrm{mM}-$ buffer eluate.

Carbohydrate associated with the enzyme was removed by a Bio-Gel P-60 column. The enzyme was concentrated and dissolved in the acetate buffer, then applied (in two separate $3.5 \mathrm{ml}$ portions) to a column $(2.2 \mathrm{~cm} \times 47 \mathrm{~cm})$ of Bio-Gel P-60 and eluted with the acetate buffer at a rate of $20 \mathrm{ml} / \mathrm{h}$. Complete separation of protein from carbohydrate was achieved. The cellulase fractions were pooled (total vol. $60 \mathrm{ml}$ ) and freeze-dried. The purified cellulase was dissolved in $6 \mathrm{ml}$ of $0.1 \mathrm{M}$-sodium acetate buffer, pH4.0.

\section{Results}

\section{Purification of cellulase}

Typical results of a purification scheme are given in Table 1. Enzyme fractions were concentrated by freeze-drying; in this procedure the salt concentration did not increase because of the volatile nature of the buffers. When desalting was necessary, for example after the $\left(\mathrm{NH}_{4}\right)_{2} \mathrm{SO}_{4}$ precipitation, dialysis in cellulose acetate tubing was avoided by the use of gel filtration. As well as removing a large quantity of protein, the DEAE-Sephadex column also removed most of the dark-brown pigment found in the crude extract. The Sephadex G-75 column separated most of the protein from the main cellulolytic peak. The elution profile of the affinity chromatography showed that although the cellulase was retarded there was incomplete separation from the contaminating protein. Some $60 \%$ of the remaining protein and the last traces of pigment were removed by adsorption on hydroxyapatite. No loss of total activity was encountered on these columns; the decrease in total units recovered is due entirely to the selection of the fractions to be pooled. Efficient removal of the carbohydrate associated with the enzyme preparation, which probably resulted from the digestion of the alkali-swollen cellulose, was achieved by gel filtration on Bio-Gel P-60.

\section{Enzyme stability}

The purified cellulase was stable indefinitely when stored as a frozen solution at $-15^{\circ} \mathrm{C}$. In addition, dilute solutions $(<10 \mu \mathrm{g} / \mathrm{ml})$ could be kept at $4^{\circ} \mathrm{C}$ for several days without significant loss of activity.

\section{Gel-electrophoresis analyses}

Analysis of the purified enzyme by gel electrophoresis at pH 5.5 revealed one major and two minor protein bands. Similar results were obtained at $\mathrm{pH} 8$ (continuous gels) and with disc gel electrophoresis. Unstained gels of the latter type were sectioned and all three bands showed cellulolytic activity. Sufficient material for kinetic analysis was obtained by running several disc gels and pooling the eluted protein from these gels. Pooling was based on the profile of enzyme activity in each gel. Each enzyme band exhibited the same pH optimum and the same $K_{\mathrm{m}}$ value towards CM-cellulose when assayed at $\mathrm{pH} 4.0$, as described below.

Table 1. Purification of a cellulase from $A$. niger

$\begin{array}{lccccc}\text { Fraction } & \begin{array}{c}\text { Volume } \\ (\mathrm{ml})\end{array} & \begin{array}{c}10^{-5} \times \text { Total } \\ \text { activity } \\ \text { (units) }\end{array} & \begin{array}{c}\text { Total } \\ \text { protein } \\ (\mathrm{mg})\end{array} & \begin{array}{c}10^{-3} \times \text { Specific } \\ \text { activity } \\ \text { (units/mg) }\end{array} & \begin{array}{c}\text { Purification } \\ \text { (fold) }\end{array} \\ & 1010 & 283 & 15900 & 1.8 & - \\ \text { SOS }_{4} \mathrm{ppt}_{\text {pt. }} & 355 & 256 & 7800 & 3.3 & 1.8 \\ \text { nded }\left(\mathrm{NH}_{4}\right)_{2} \mathrm{SO}_{4} \mathrm{ppt.} & 600 & 192 & 5700 & 3.4 & 1.9 \\ \text { eluate } & 50 & 80 & 2250 & 3.6 & 2.0 \\ \text { eluate } & 14 & 50 & 415 & 12.0 & 6.7 \\ \text { eluate } & 15 & 33 & 138 & 23.9 & 13.3 \\ \text { eluate } & 7.7 & 24 & 55.4 & 43.3 & 23.9 \\ \text { ate } & 5.8 & 23.5 & 52.0 & 45.2 & 25.1\end{array}$

\section{Crude extract}

$80 \%$-satd.-( $\left(\mathrm{NH}_{4}\right)_{2} \mathrm{SO}_{4} \mathrm{ppt}$

Desalted resuspended $\left(\mathrm{NH}_{4}\right)_{2} \mathrm{SO}_{4} \mathrm{ppt}$.

DEAE-Sephadex eluate

Sephadex G-75 eluate

Affinity-column eluate

Hydroxyapatite eluate

Bio-Gel P-60 eluate

Vol. 165 
SDS/polyacrylamide-gel electrophoresis of the purified enzyme $(25 \mu \mathrm{g})$ revealed one protein band with a molecular weight of $26000 \pm 500$ calculated from a standard curve.

\section{Gel chromatography}

The molecular weight of the cellulase from the calibrated P-60 column was $26000 \pm 2000$, by using ribonuclease (12600), $\alpha$-chymotrypsin (21600), $\alpha$ amylase (45000) and bovine serum albumin (68400) as standards (Smith, 1968).

\section{Ultracentrifugal analysis}

A single symmetrical peak of material was observed when the cellulase was sedimented in the ultracentrifuge (rotor speed $56000 \mathrm{rev} . / \mathrm{min}$; temperature $\left.20^{\circ} \mathrm{C}\right)$. The $s_{20, w}$ of the cellulase $(10 \mathrm{mg} / \mathrm{ml})$ was $2.4 \mathrm{~S}$ in $0.05 \mathrm{M}$-sodium acetate buffer, $\mathrm{pH} 5.0$, and $2.6 \mathrm{~S}(9 \mathrm{mg} / \mathrm{ml})$ in $0.1 \mathrm{M}-\mathrm{Tris} / \mathrm{HCl}$ buffer, $\mathrm{pH} 8.0$.

\section{Amino acid analysis}

The results of the amino acid analysis are given in Table 2 . The enzyme contains a high proportion of acidic and aromatic amino acids, but is low in sulphur-containing and basic amino acids. The total number of residues was calculated as $241 \pm 1$, which indicated a molecular weight of about 26000 .
Table 2. Amino acid composition of a cellulase from A. niger Total number of residues $=241$; molecular weight from closest integer $=25900$.

\begin{tabular}{lcc} 
& \multicolumn{2}{c}{$\begin{array}{c}\text { Content } \\
\text { (residues/molecule) }\end{array}$} \\
\cline { 2 - 3 }$\quad$ Amino acid & Determined & Closest integer \\
Lysine & 8.3 & 8 \\
Histidine & 3.6 & 4 \\
Arginine & 2.0 & 2 \\
Aspartic acid & 28.0 & 28 \\
Threonine & 23.8 & 24 \\
Serine & 26.2 & 26 \\
Glutamic acid & 23.8 & 24 \\
Proline & 9.7 & 10 \\
Glycine & 27.9 & 28 \\
Alanine & 20.3 & 20 \\
Half-cystine & $0^{*}, 0.8 \dagger$ & $0-1$ \\
Valine & 15.9 & 16 \\
Methionine & 2.7 & 3 \\
Isoleucine & 9.0 & 9 \\
Leucine & 6.6 & 7 \\
Tyrosine & 15.2 & 15 \\
Phenylalanine & 10.8 & 11 \\
Tryptophan & $6.2 \ddagger, 6.3 \S$ & 6
\end{tabular}

* Free thiol group in native or denatured cellulase.

$\dagger$ Free thiol group in reduced cellulase.

$\ddagger$ Determined in guanidine hydrochloride.

$\S$ Determined with 2-nitrophenylsulphenyl chloride.

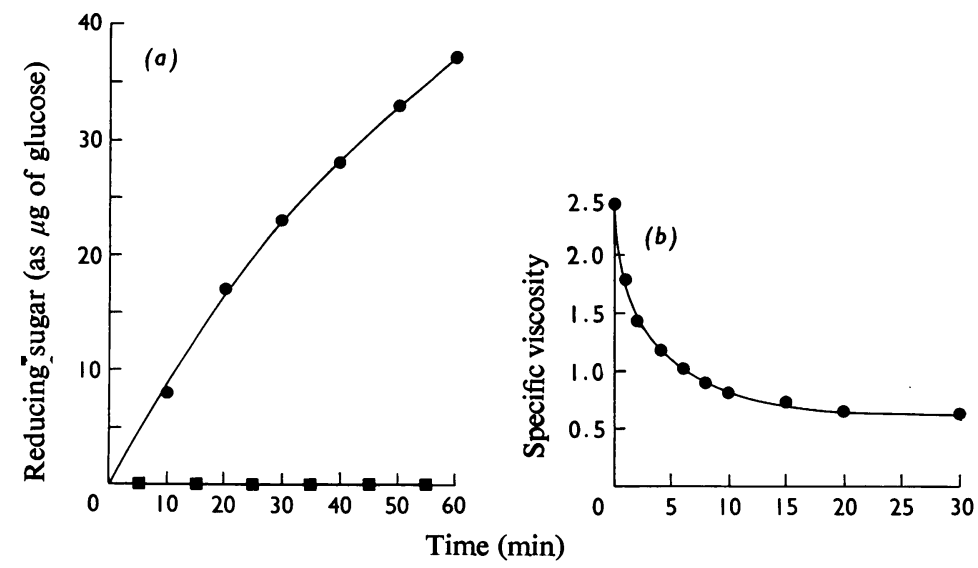

Fig. 1. Hydrolysis of CM-cellulose

(a) Production of reducing sugars during the hydrolysis of CM-cellulose. Each assay contained $0.1 \mathrm{ml}$ of enzyme solution $(0.25 \mu \mathrm{g})$ and $0.5 \mathrm{ml}$ of CM-cellulose $(10 \mathrm{mg} / \mathrm{ml})$ in $0.1 \mathrm{M}$-sodium acetate buffer, $\mathrm{pH} 4.0$ at $40^{\circ} \mathrm{C}$. Tubes were removed from the incubation bath at the times indicated, kept on ice and reducing sugars $(\bullet)$ and glucose $(\boldsymbol{\square})$ determined as described under 'Methods'. (b) Effect of cellulase on the viscosity of CM-cellulose solution. Solutions of CM-cellulose $(20 \mathrm{mg} / \mathrm{ml}$, in $0.1 \mathrm{M}$-sodium acetate buffer, $\mathrm{pH} 4.0,30 \mathrm{ml})$ and cellulase $(25 \mu \mathrm{g} / \mathrm{ml}$, in the same buffer, $5 \mathrm{ml})$ were mixed and $5 \mathrm{ml}$ samples were removed at the times indicated for the determinations with an Ostwald viscometer. The specific viscosity at zero time was determined by substituting buffer for the enzyme solution. The experiment was carried out in a constant-temperature room at $40^{\circ} \mathrm{C}$. 


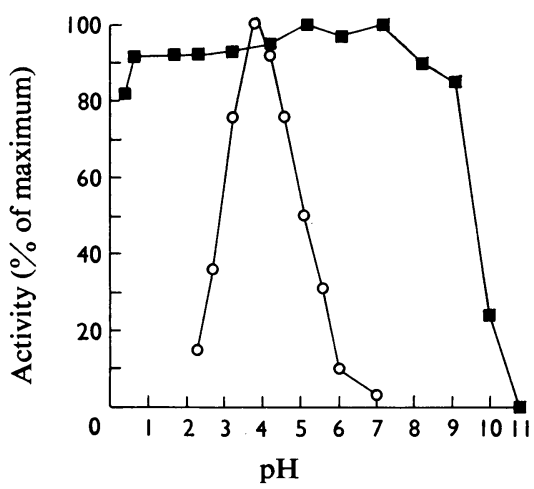

Fig. 2. Effect of the $p H$ on the activity and stability of cellulase

The effect of $\mathrm{pH}$ on the enzymic hydrolysis of CMcellulose $(O)$ was measured in the assay system consisting of $0.25 \mathrm{ml}$ of CM-cellulose $(20 \mathrm{mg} / \mathrm{ml})$ in water, $0.25 \mathrm{ml}$ of an appropriate buffer and $0.1 \mathrm{ml}$ of cellulase $(0.25 \mu \mathrm{g})$. Buffers used were: $0.2 \mathrm{M}$-glycine $/ \mathrm{HCl}$ (pH1.5, 2.0, 2.5); $0.2 \mathrm{M}$-citric acid/NaOH (pH3.0, 3.5); 0.2 $\mathrm{M}$-acetic acid/NaOH (pH4.0, 4.5, 5.0, 5.5); $0.2 \mathrm{M}$-succinic acid/NaOH (pH5.0, 5.5, 6.0); 0.2 $\mathrm{M}-$ imidazole $/ \mathrm{HCl}$ ( $\mathrm{pH} 4.0$ ). Points were the average of three determinations. In determining the stability of the enzyme ( $\square$ ), cellulase was incubated at $25^{\circ} \mathrm{C}$ for $24 \mathrm{~h}$ in a mixture containing $0.5 \mathrm{ml}$ of buffer, $0.4 \mathrm{ml}$ of water and $0.1 \mathrm{ml}$ of enzyme solution $(250 \mu \mathrm{g} / \mathrm{ml})$. After incubation, $0.1 \mathrm{ml}$ samples were transferred to $1.0 \mathrm{ml}$ of $0.25 \mathrm{M}$-sodium acetate buffer, $\mathrm{pH} 4.0$. Duplicate assays were carried out on $0.1 \mathrm{ml}$ portions. Buffers used were: $0.2 \mathrm{M}$-glycine $/ \mathrm{HCl}(\mathrm{pH} 1.5,2.0)$; $0.2 \mathrm{M}$-citric acid/NaOH (pH3.0, 4.0, 5.0, 6.0); 0.2 $\mathrm{M}$ imidazole/ $\mathrm{HCl}$ (pH 7.0); 0.2 $\mathrm{M}$-Tris/ $\mathrm{HCl}$ (pH 8.0, 9.0); $0.2 \mathrm{M}$-glycine $/ \mathrm{NaOH}(\mathrm{pH} 10) ; 0.2 \mathrm{M}-\mathrm{NaHCO}_{3} / \mathrm{NaOH}$ (pH11.0). For $\mathrm{pH}$ values below 1 dilute $\mathrm{HCl}$ solutions (approx. $0.5 \mathrm{M}$ ) were used. The $\mathrm{pH}$ of each incubation was measured after mixing the component solutions.

\section{Nature of the enzyme action}

The purified cellulase was tested for the presence of both cellobiase and $\beta$-glucosidase as described under 'Methods'; neither of these activities, however, could be detected. The progress of the hydrolysis of CM-cellulose was followed by monitoring reducing end-group production (Fig. 1a). No glucose was detected, which suggested an endo- rather than exocellulolytic mode of action. Further, hydrolysis of CM-cellulose was accompanied by a rapid decrease in the viscosity of the solution (Fig. 1b).

\section{Effect of $p H$}

The effect of the $\mathrm{H}^{+}$concentration on the activity and stability of the cellulase is shown in Fig. 2. Hydrolysis of CM-cellulose was confined to acid media, being maximal at $\mathrm{pH} 3.8-4.0$. In contrast with the sharp $\mathrm{pH}$ optimum seen in the activity profile, the cellulase was stable in the absence of substrate, over a wide range of $\mathrm{pH}$ values.

\section{Effect of temperature}

A temperature of $40^{\circ} \mathrm{C}$ was used in the standard assay; however, the temperature of maximum activity under these conditions proved to be $45^{\circ} \mathrm{C}$ (Fig. $3 a$ ). At $\mathrm{pH} 4.0$, close to the optimum for activity, the cellulase was extremely sensitive to temperatures above $60^{\circ} \mathrm{C}$ (Fig. $3 b$ ). In contrast, at pH8.0 enzyme activity decreased gradually at temperatures above $40^{\circ} \mathrm{C}$, but was not completely lost until $100^{\circ} \mathrm{C}$.

Results of a subsequent experiment, designed to yield data on the effect of $\mathrm{pH}$ on heat-denaturation (at two fixed temperatures) of the purified cellulase, are shown in Fig. 3(c). The cellulase was remarkably unstable at $60^{\circ} \mathrm{C}$ in the $\mathrm{pH}$ range for greatest activity. At $50^{\circ} \mathrm{C}$, however, the cellulase was relatively stable over the $\mathrm{pH}$ range used.

\section{Kinetics}

Typical saturation curves of the purified enzyme acting on CM-cellulose at different $\mathrm{pH}$ values indicated that substrate saturation of the enzyme was not achieved above pH3.5. Table 3 summarizes $K_{\mathrm{m}}$ and $V$ values from several different experiments. The highest $V$ was obtained at $\mathrm{pH} 4.5-5.0$, whereas the $\mathrm{pH}$ optimum under the standard assay conditions

Table 3. Variation in kinetic parameters of cellulase with pH

$V$ and $K_{\mathrm{m}}$ values were determined at different $\mathrm{pH}$ values. Each assay contained $0.5 \mathrm{ml}$ of buffered substrate solution and $0.1 \mathrm{ml}$ of enzyme solution $(0.1 \mu \mathrm{g}$ of protein). Stock solutions $(40 \mathrm{mg} / \mathrm{ml})$ of CM-cellulose were prepared in $0.1 \mathrm{M}$ buffers adjusted if necessary with either $6 \mathrm{M}-\mathrm{HCl}$ or $5 \mathrm{M}-\mathrm{NaOH}$, then diluted with the appropriate buffer to $30,25,20,15$, $10,7.5,5.0$ or $2.5 \mathrm{mg}$ of CM-cellulose $/ \mathrm{ml}$. Buffers used were $0.1 \mathrm{M}$-glycine $/ \mathrm{HCl}, \mathrm{pH} 2.5 ; 0.1 \mathrm{M}$-citric acid/NaOH, pH3.0, pH3.5; $0.1 \mathrm{M}$-acetic acid/NaOH, pH4.0, pH4.5, pH5.0, pH5.5; 0.1 M-succinic acid/ $\mathrm{NaOH}, \mathrm{pH} 6.0$. Values given are the ranges obtained from the number of determinations shown in parentheses.

pH $V$ (units $/ \mu$ g of protein) (mg of CM-cellulose $/ \mathrm{ml}$ )

$\begin{array}{lccc}2.5 & 10.8-11.2(3) & 1.3-1.4(3) \\ 3.0 & 25.7-31.5(4) & 4.0-6.3(4) \\ 3.5 & 46.2-60.9(4) & 5.3-9.2(4) \\ 4.0 & 85-106(5) & 14.5-17.3(5) \\ 4.5 & 108-140(4) & 30-39(4) \\ 5.0 & 127-207(4) & 52-80(4) \\ 5.5 & 36.5-47.5(4) & 40-55(5) \\ 6.0 & 11.0-16.4(4) & 21-30 \quad(4)\end{array}$



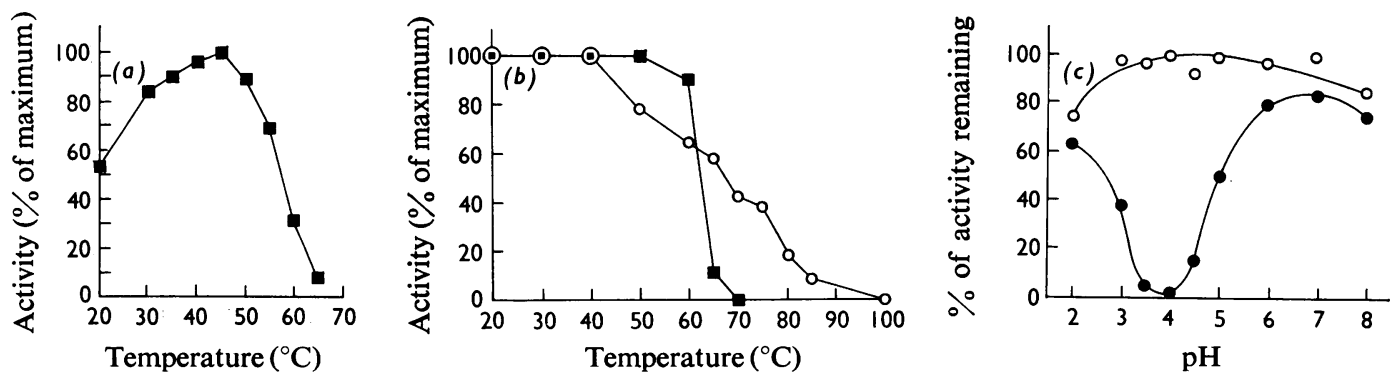

Fig. 3. Effect of heat on cellulase

(a) Variation of cellulase activity with temperature. Enzyme $(0.2 \mu \mathrm{g})$ was assayed in the standard system, except that the temperatures were varied as shown. Points are the average of duplicate determinations. (b) Stability of cellulase at different temperatures and two $\mathrm{pH}$ values. Cellulase solutions $(1.0 \mathrm{ml}$, containing $24 \mu \mathrm{g})$ in $0.1 \mathrm{M}-\mathrm{acetic}$ acid/ $\mathrm{NaOH}$, pH4.0 buffer ( $\square$ ), or $0.1 \mathrm{M}$-phosphoric acid/ $\mathrm{NaOH}, \mathrm{pH} 8.0$ buffer $(\mathrm{O})$, was incubated for $1 \mathrm{~h}$ at the temperatures indicated, diluted with $9.0 \mathrm{ml}$ of cold $0.1 \mathrm{M}$-acetate buffer, $\mathrm{pH} 4.0$, and then $0.1 \mathrm{ml}$ samples were assayed by the standard procedure. Points are average of duplicate determinations. (c) Effect of pH on the stability of cellulase at $65^{\circ} \mathrm{C}$ and $50^{\circ} \mathrm{C}$. Buffered solutions of cellulase $(1 \mathrm{ml}$ containing $20 \mu \mathrm{g})$ were incubated for $30 \mathrm{~min}$, at $65^{\circ}(\bullet)$ or $50^{\circ} \mathrm{C}(\circ)$, cooled and diluted with $9.0 \mathrm{ml}$ of $0.1 \mathrm{M}$-sodium acetate buffer, pH4.0. Duplicate assays were carried out with $0.1 \mathrm{ml}$ samples; $100 \%$ activity remaining represents the sample treated at $20^{\circ} \mathrm{C}$ and $\mathrm{pH} 4.0$. Buffers used were: $0.1 \mathrm{M}-\mathrm{glycine} / \mathrm{HCl}$, pH 2.0; 0.1 M-formic acid/ $\mathrm{NaOH}, \mathrm{pH} 3.0,3.5 ; 0.1 \mathrm{~m}$-acetic acid/NaOH, pH4.0, 4.5, 5.0; 0.05 M-Mes (4-morpholineethanesulphonic acid)/ $\mathrm{NaOH}, \mathrm{pH} 6.0 ; 0.05 \mathrm{M}$-Tes (2-\{[2-hydroxy-1,1-bis(hydroxymethyl)ethyl]aminoethanesulphonic acid\})/ $\mathrm{NaOH}, \mathrm{pH} 7.0 ; 0.05 \mathrm{M}$-Tris/HCl, $\mathrm{pH} 8.0$.
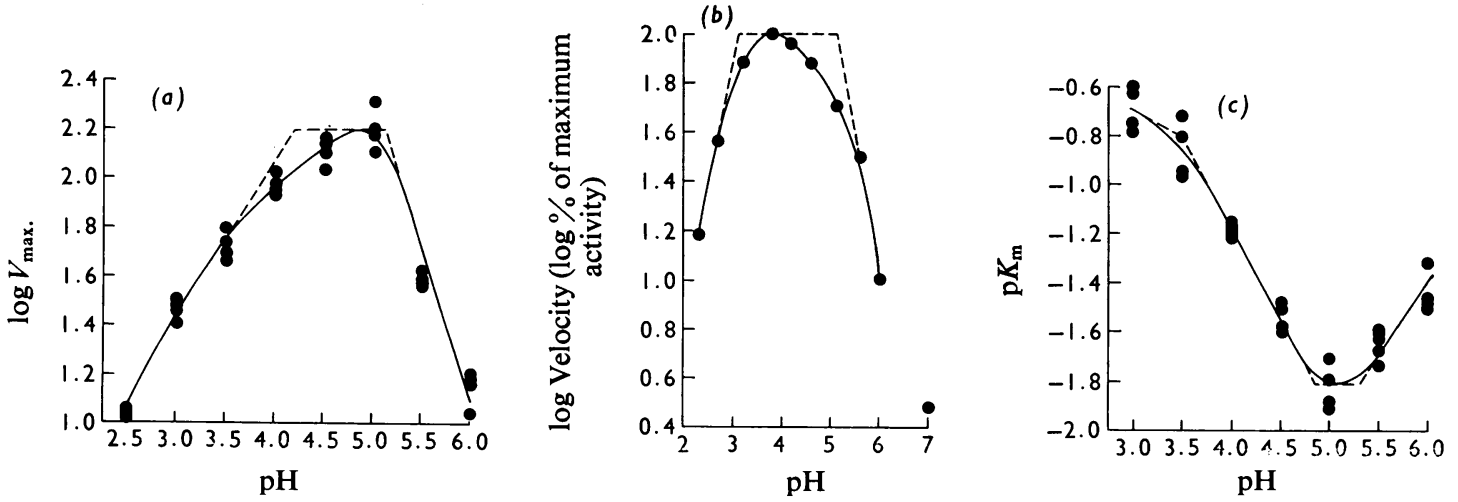

Fig. 4. Effect of pHon the kinetic parameters of cellulase

(a) Variation of $\log V$ with $\mathrm{pH}$. $\log V$ values were derived from the data in Table 3 . The points represent different experimental determinations. (b) Variation of $\log v$ with pH. The $\log$ of relative $v$ values shown in Fig. 2 are plotted versus pH. (c) Variation of $\mathrm{p} K_{\mathrm{m}}$ with $\mathrm{pH} . \mathrm{p} K_{\mathrm{m}}\left(-\log K_{\mathrm{m}}\right)$ values obtained from experiments as described in Table 3 are plotted versus $\mathrm{pH}$. Each point represents a separate experimental determination. In $(a),(b)$ and $(c)$ the dashed lines are extrapolations of the linear portions of the curves, used in the estimation of $\mathrm{p} K$ values.

(Fig. 2) was pH3.8. By using the analysis of Dixon \& Webb (1964), the log $V$ versus pH plot (Fig. $4 a$ ) gave $\mathrm{p} K_{\mathrm{ES}}$ values of 4.2 and 5.1 for groups in the enzymesubstrate complex. The plot of $\log v$ versus $\mathrm{pH}$ (Fig. $4 b$ ) revealed $\mathrm{p} K$ values of 3.1 and 5.1 , which approximate to the $\mathrm{p} K$ values of groups on either the free enzyme or free substrate. Further indication of $\mathrm{p} K_{\mathrm{ES}}$ values was obtained from the $\mathrm{p} K_{\mathrm{m}}$ versus $\mathrm{pH}$ graph (Fig. 4c), which gave values of 4.8 and 5.3. The break at pH 3.6 may be due to the ionization of the substrate
(King \& Smibert, 1963). Slopes of \pm 1 were obtained only from the $\log v$ versus $\mathrm{pH}$ plot; the slopes obtained from the $\log V$ versus $\mathrm{pH}$ and $\mathrm{p} K_{\mathrm{m}}$ versus $\mathrm{pH}$ plots were $+0.6,-1.2$ and $+0.6,-0.7$ respectively.

\section{Discussion}

Determination of cellulase activity with $p$-hydroxybenzoic acid hydrazide was preferred to other methods for two reasons. One was the greater sensi- 
tivity of the method compared with the commonly used dinitrosalicyclic acid procedure (Sumner \& Sisler, 1944; Miller et al., 1960); the latter has a lower limit of sensitivity of $100 \mu \mathrm{g}$ of glucose equivalent, compared with 1-2 $\mu \mathrm{g}$ for the $p$-hydroxybenzoic acid hydrazide. Further, destruction of reducing sugars is not encountered with $p$-hydroxybenzoic acid hydrazide, but is apparent with the dinitrosalicylic acid method(Miller et al., 1960). Second, although the copper-reagent method of Nelson (1944) and Somogyi (1952) has sensitivity comparable with that of $p$ hydroxybenzoic acid hydrazide, the former suffers from the disadvantage that the assay involves three successive manipulations. When large numbers of assays are to be performed, for example in the elucidation of a purification scheme, it is desirable to have a rapid assay system involving a minimum number of steps; this criterion is met by the $p$-hydroxybenzoic acid hydrazide method.

Fractionation of the crude cellulase preparation into as many different cellulolytic components as possible was not the objective of this work. The purification scheme was designed for the isolation of one homogeneous cellulase from several elaborated by A. niger. Ikeda et al. (1967) obtained four cellulases from $A$. niger, but the purity of these fractions was not described. Subsequently a modified procedure was designed for the isolation of a specific homogeneous cellulase (Ikeda et al., 1973a). Clarke \& Stone (1965a) had reported the purification of a $\beta$ - $(1 \rightarrow 4)$-glucan hydrolase from a crude $A$. niger extract, and subsequently described some enzymic properties of that cellulase (Clarke \& Stone, 1965b). The physicochemical and enzymic properties reported in the present paper indicate that this enzyme is different from previously described $A$. niger cellulases.

Table 1 shows that the cellulase has been purified 25-fold compared with the crude extract. This value is undoubtedly an underestimate of the effectiveness of the purification. The assay does not distinguish between cellulolytic activities, and hence the usefulness of a particular purification step in isolating a single activity may not be immediately apparent. It could well be that the purification achieved in the present work is, in reality, several hundredfold.

Evidence for the homogeneity of the cellulase comes from the SDS/polyacrylamide-gel electrophoresis experiments and the sedimentation studies: both of these techniques indicated a single protein species. Further, the cellulase migrated as a single symmetrical peak on the gel-filtration columns used for molecular-weight estimation.

Generally the mol.wt. of cellulases is low, ranging from 5600 (Selby \& Maitland, 1965) to 76000 (Li et al., 1965). The mol.wt. of 26000 obtained from the SDS/polyacrylamide-gel electrophoresis, amino acid composition and gel-filtration data is compatible with the determined sedimentation coefficient of $2.5 \pm$ $0.1 \mathrm{~S}$. These experiments, together with the chemical analyses, indicate that the cellulase is a single polypeptide chain devoid of disulphide linkages and carbohydrate. A cellulase from $A$. niger, with a mol.wt. and sedimentation coefficient of 46000 and 3.27S respectively, containing both glucosamine and arabinose has been reported (Ikeda et al., 1973a,b).

The rapid decrease in the specific viscosity of CMcellulose solutions accompanied by a small increase in reducing sugars (Fig. 1) is compatible with a random hydrolysis of the substrate. In this respect the cellulase resembles components 3, 4, 5 and 6 from $A$. niger of King \& Smibert (1963) and the $A$. niger cellulase of Clarke \& Stone (1965b). Although Ikeda et al. (1967) observed similar results with their 'glycol cellulose' as substrate, they concluded that $A$. niger cellulases were exoglucanases because release of reducing sugars from filter paper did not result in visual paper breakdown. The validity of their conclusion is questionable.

The pH-activity profile (Fig. 2) showed a sharp optimum at pH3.8-4.0. Clarke \& Stone (1965b) published a profile with a rather broad optimum in the range pH4-6 obtained with an $A$. niger cellulase and CM-cellulose. The cellulase from $A$. niger reported by Ikeda et al. $(1973 a, b)$ is characterized by a pH optimum for activity towards their 'glycol cellulose' at $\mathrm{pH} 2.5$.

Although the cellulase retained $90 \%$ of its activity after heating at $60^{\circ} \mathrm{C}$ and $\mathrm{pH} 4$ for $1 \mathrm{~h}$ (Fig. $3 b$ ), the enzymic effectiveness was much decreased at that temperature (Fig. 3a). This observation implies that the decrease in activity from $45^{\circ}$ to $65^{\circ} \mathrm{C}$ cannot be fully explained by enzyme instability at these temperatures. Hence, the temperature optimum determined in this experiment cannot be classically described as the balance between the effect of temperature on catalysis and the effect of temperature on the rate of enzyme denaturation. The presence of substrate did not affect the heat stability of the enzyme. Temperatures greater than $60^{\circ} \mathrm{C}$ (at $\left.\mathrm{pH} 4\right)$ resulted in irreversible inactivation. In contrast, gradual loss of stability with increasing temperature at $\mathrm{pH} 8$ suggested that the $\mathrm{H}^{+}$concentration had a role in the temperature stability of the cellulase. This was substantiated by the results in Fig. $3(c)$ : at $65^{\circ} \mathrm{C}$ the stability of the enzyme was markedly $\mathrm{pH}-$ dependent, being least stable at $\mathrm{pH}$ values where activity $\left(\right.$ at $40^{\circ} \mathrm{C}$ ) is maximal. At $50^{\circ} \mathrm{C}$, however, enzymic activity was retained throughout the greater part of the $\mathrm{pH}$ range used. These results can be explained by postulating modified forms of the enzyme as shown in Scheme 1.

$E$, as the low-temperature form of the enzyme at about $\mathrm{pH} 4$, is reversibly converted into an inactive or partially active form $\left(\mathrm{E}^{\prime}\right)$ at temperatures up to $60^{\circ} \mathrm{C}$. At temperatures greater than $60^{\circ} \mathrm{C}(\mathrm{pH} 4)$ this state is

Vol. 165 


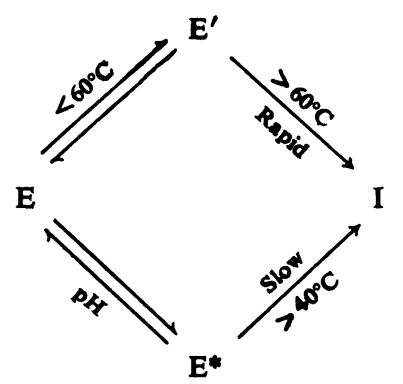

Scheme 1. Possible modified forms and related pathways of the cellulase

For details see the text.

rapidly and irreversibly denatured (I). $\mathrm{E}^{*}$ is a species of enzyme that predominates at $\mathrm{pH}$ values greater than 6 , where catalysis is poor, and is characterized by a relatively slow rate of heat inactivation. A corresponding state may exist at low $\mathrm{pH}$ values. In view of the remarkable similarity of the curve obtained at $65^{\circ} \mathrm{C}$ (Fig. $3 c$ ) and the inverse of the $\mathrm{pH}$-activity profile (Fig. 2), it is tempting to speculate that the ionization of those groups on the enzyme responsible for the catalysis is also involved in the temperature stability of the enzyme.

Graphical analyses gave four $\mathrm{p} K$ values for groups involved in the enzyme-substrate complex. It is not possible to say with certainty that these values are indicative of two, three or four unique amino acid residues. Comparisons of Fig. 4(b) with Figs. 4(a) and 4(c) show that the interaction of the enzyme and substrate results in significant perturbation of the $\mathrm{p} K$ of one of the groups in the enzyme (3.1 increases to either 4.2 or 4.8). The observation that the slopes from the plots $\log V$ against $\mathrm{pH}$ and $\mathrm{p} K_{\mathrm{m}}$ against $\mathrm{pH}$ are not \pm 1 implies that a simple model of the pH-dependence of cellulase action is insufficient to describe the cellulase-CM-cellulose system. Wakim et al. (1969) come to a similar conclusion when they reported gross divergence from unit slopes in the $\log V$ versus pH plot obtained with pig pancreatic $\alpha$-amylase acting on starch. Hydrolysis of the nitrophenyl glycoside of $N$-acetylglucosaminyl- $\beta$-(1,4)-glucose by lysozyme showed complex pH-dependence of the kinetic constants in the acid region; a slope of 0.6 was obtained from the $\log V / K_{\mathrm{m}}$ versus $\mathrm{pH}$ plot by Rand-Meir et al. (1969) and they suggested that this effect might have been due to the interaction of two ionizable groups in lysozyme.

The $\mathrm{p} K$ values obtained indicate that carboxyl groups may be involved in cellulase catalysis. A wealth of evidence exists for the involvement of carboxyl groups in the catalytic mechanism of lysozyme (for reviews see Osserman et al., 1974). In view of the functional similarity between lysozyme and cellulase (both cleave $\beta$-1,4-glucosidic bonds) it is tempting to speculate that a similar situation occurs in cellulase, with a carboxyl group acting as a general acid, protonating the leaving groups.

We are grateful to Mr. P. A. Stockwell for devising the computer programs. This work was supported in part by grants from the New Zealand University Grants Committee and the Medical Research Council of New Zealand.

\section{References}

Andrews, P. (1964) Biochem. J. 91, 222-232

Clarke, A. E. \& Stone, B. A. (1965a) Biochem. J. 96, 793-801

Clarke, A. E. \& Stone, B. A. (1965b) Biochem. J. 96, 802-807

Dixon, M. \& Webb, E. G. (1964) Enzymes, 2nd edn., pp. 116-145, Longmans Green, London

Edelhoch, H. (1967) Biochemistry 6, 1948-1954

Eggstein, M. \& Kreutz, F. H. (1967) in Techniques in Protein Chemistry (Bailey, J. L., ed.), p. 340, Elsevier, London

Eisenthal, R. \& Cornish-Bowden, A. (1974) Biochem. J. 139, 715-720

Habeeb, A. F. S. A. (1972) Methods Enzymol. 25, 457-464

Hash, J. H. \& King, K. W. (1958) J. Biol. Chem. 232, 381-393

Hedrick, J. L. \& Smith, A. J. (1968) Arch. Biochem. Biophys. 126, 155-164

Hjertén, S., Jerstedt, S. \& Tisélius, A. (1965) Anal. Biochem. 11, 219-223

Ikeda, R., Yamamoto, T. \& Funatsu, M. (1967) Agric. Biol. Chem. 31, 1201-1209

Ikeda, R., Yamamoto, T. \& Funatsu, M. (1973a) Agric. Biol. Chem. 27, 1153-1159

Ikeda, R., Yamamoto, T. \& Funatsu, M. (1973b) Agric. Biol. Chem. 37, 1169-1175

Krishna Murti, C. R. \& Stone, B. A. (1961) Biochem. J. 78, 715-723

King, K. W. \& Smibert, R. M. (1963) Appl. Microbiol. 11, 315-319

Lever, M. (1973) Biochem. Med. 7, 274-281

Li, L. H. \& King, K. W. (1963) Appl. Microbiol. 11, 320-325

Li, L. H., Flora, R. M. \& King, K. W. (1965) Arch. Biochem. Biophys. 111, 439-447

Lloyd, J. B. \& Whelan, W. J. (1969) Anal. Biochem. 30, $467-470$

Lowry, O. H., Rosebrough, N. J., Farr, A. L. \& Randall, R. J. (1951) J. Biol. Chem. 193, 265-275

Miller, G. L., Blum, R., Glennon, W. E. \& Burton, A. L. (1960) Anal. Biochem. 2, 127-132

Nelson, N. (1944) J. Biol. Chem. 153, 375-380

Osserman, E. F., Canfield, R. E. \& Beychok, S. (eds.) (1974) Lysozyme, Academic Press, New York and London

Pettersson, G. (1963) Biochim. Biophys. Acta 71, 665-667

Rand-Meir, T., Dahlquist, F. W. \& Raftery, M. A. (1969) Biochemistry 8, 4206-4124

Schachman, H. K. (1957) Methods Enzymol. 4, 32-103 
Scoffone, E., Fontana, A. \& Rocchi, R. (1968) Biochemistry 7, 971-979

Selby, K. \& Maitland, C. C. (1965) Biochem. J. 94, 578-583

Smith, M. H. (1968) in Handbook of Biochemistry (Sober, H. A., ed.), pp. C3-C47, The Chemical Rubber Co., Cleveland

Somogyi, M. (1952) J. Biol. Chem. 195, 19-23

Sumner, J. B. \& Sisler, E. B. (1944) Arch. Biochem. 4, 333-336
Svennerholm, L. (1956) J. Neurochem. 1, 42-53

Wakim, J., Robinson, M. \& Thoma, J. A. (1969) Carbohydr. Res. 10, 487-503

Weber, K. \& Osborn, M. (1969) J. Biol. Chem. 244, 44064412

Whistler, R. L. \& Smart, C. L. (1953) J. Am. Chem. Soc. 75, 1916-1918

Wolf, M. J., Jurkovitch, V. \& MacMasters, M. M. (1959) Arch. Biochem. Biophys. 81, 15-24 